\title{
SISTEM PAKAR UNTUK DIAGNOSA PENYAKIT KEHAMILAN MENGGUNAKAN METODE DEMPSTER-SHAFER DAN DECISION TREE
}

\author{
Joko Minardi \\ Fakultas Sains dan Teknologi, Program Studi Sistem Informasi \\ Universitas Islam Nahdlatul Ulama Jepara \\ Email: joko@unisnu.ac.id \\ Suyatno \\ Fakultas Sains dan Teknologi, Program Studi Sistem Informasi \\ Universitas Islam Nahdlatul Ulama Jepara \\ Email: yatno@unisnu.ac.id
}

\begin{abstract}
ABSTRAK
Teori Dempster-Shafer adalah teori matematika bukti berdasarkan fungsi keyakinan dan penalaran yang masuk akal, yang digunakan untuk menggabungkan bagian yang terpisah dari informasi. DempsterShafer teori alternatif teori probabilistik tradisional untuk representasi matematis dari ketidakpastian. Dalam diagnosis penyakit informasi kehamilan yang diperoleh dari pasien kadang-kadang tidak lengkap, dengan metode dan sistem pakar Dempster-Shafer aturan bisa menjadi kombinasi dari gejala yang tidak lengkap untuk mendapatkan diagnosis yang tepat sedangkan pohon keputusan digunakan sebagai alat pendukung keputusan pelacakan referensi gejala penyakit. Penelitian ini bertujuan untuk mengembangkan sebuah sistem pakar yang dapat melakukan diagnosis kehamilan menggunakan metode Dempster Shafer, yang dapat menghasilkan nilai kepercayaan untuk diagnosis penyakit. Berdasarkan hasil tes diagnostik Dempster-Shafer metode dan ahli sistem, akurasi yang dihasilkan dari $76 \%$.
\end{abstract}

Kata kunci: sistem ahli, penyakit kehamilan, dempster shafer.

\begin{abstract}
Dempster-Shafer theory is a mathematical theory of evidence based on belief functions and plausible reasoning, which is used to combine separate pieces of information. Dempster-Shafer theory an alternative to traditional probabilistic theory for the mathematical representation of uncertainty. In the diagnosis of diseases of pregnancy information obtained from the patient sometimes incomplete, with Dempster-Shafer method and expert system rules can be a combination of symptoms that are not complete to get an appropriate diagnosis while the decision tree is used as a decision support tool reference tracking of disease symptoms This Research aims to develop an expert system that can perform a diagnosis of pregnancy using Dempster Shafer method, which can produce a trust value to a disease diagnosis. Based on the results of diagnostic testing Dempster-Shafer method and expert systems, the resulting accuracy of $76 \%$.
\end{abstract}

Keywords: expert system; diseases of pregnancy; dempster shafer.

\section{PENDAHULUAN}

Perkembangan dunia teknologi informasi telah banyak mengalami perubahan yang pesat, seiring dengan kebutuhan manusia akan teknologi informasi. Hal ini mendorong para ahli untuk mengembangkan komputer agar dapat membantu kerja manusia. Salah satu ilmu komputer yang dapat membantu mengembangkan komputer untuk membantu kerja manusia adalah sistem pakar (Expert System). Implementasi sistem pakar dapat digunakan diberbagai bidang salah satunya bidang kesehatan

Kurangnya informasi mengenai penyakit pada masa kehamilan, rasa malu dan tertutup untuk berkonsultasi secara langsung mengenai kesehatan kehamilan, terutama bila dokter obstetri dan ginekologi seorang pria. Serta masih banyak yang menggunakan cara-cara tradisional yang tidak jarang kontra-produktif dengan keadaan tubuh. Oleh karena itu, maka perlu diberikan informasi yang jelas tentang penyakit kehamilan. Penelitian ini dilakukan untuk membuat sebuah sistem pakar, Sistem pakar disini akan mendiagnosa suatu penyakit kehamilan dengan pilihan gejala yang dirasakan, dari gejala yang ada selanjutnya dihasilkan diagnosa penyakit yang sedang diderita, dalam penerapan sistem pakar ini digunakan metode Dempster-Shafer untuk proses diagnosa penyakit kehamilan. 
Ada beberapa metode yang dapat diterapkan didalam sistem pakar, dan salah satunya adalah metode dempster shafer, Dempster-Shafer adalah suatu teori matematika untuk pembuktian berdasarkan belief functions and plausible reasoning (fungsi kepercayaan dan pemikiran yang masuk akal), yang digunakan untuk mengkombinasikan potongan informasi yang terpisah (bukti) untuk mengkalkulasi kemungkinan dari suatu peristiwa. Teori ini dikembangkan oleh Arthur P. Dempster dan Glenn Shafer. Salah satu pengimplementasian sistem pakar menggunakan metode dempster shafer adalah diterapkan dalam bidang kedokteran untuk diagnosa suatu penyakit.

Teori Dempster-Shafer dalam perkembangannya telah digunakan untuk melakukan pemetaan wilayah pada penelitian tentang penyakit flu burung, dengan output berupa tampilan grafis pemetaan wilayah [4], kemudian pengembangan algoritma untuk mengatasi klasifikasi data yang tidak sempurna dengan hasil berupa object yang mendekati sama dengan aslinya [8], selanjutnya pengenalan huruf dan angka telugu hasil dari penelitian ini adalah bahwa tingkat kesalahan uji sangat minim [5], penelitian berkutnya teknik pencampuran data untuk mendeteksi bangunan serta optimalisasi klasifikasi penggunaan lahan dimana Hasil penelitian ini menunjukkan arah deteksi yang efektif dan kuat sebuah bangunan dengan tingkat keberhasilan lebih dari 80 persen dan berdasarkan wilayah pengujian menunjukkan, hasilnya juga menggembirakan [2]. Pada penelitian ini teori Dempster-Shafer digunakan untuk membuat sistem pakar untuk diagnosa penyakit kehamilan.

\section{KERANGKA TEORI}

\subsection{Sistem Pakar}

Sistem pakar disusun oleh dua bagian utama, yaitu lingkungan pengembangan (development environment) dan lingkungan konsultasi (consultation environment) [7]. Lingkungan pengembangan sistem pakar digunakan untuk memasukkan pengetahuan pakar ke dalam lingkungan sistem pakar, sedangkan lingkungan konsultasi digunakan oleh pengguna yang bukan pakar untuk memperoleh pengetahuan pakar.

\subsection{Pohon Keputusan (Decision Tree)}

Pohon keputusan adalah alat pendukung keputusan yang menggunakan struktur pohon hierarkis untuk mengklasifikasikan kelas berdasarkan serangkaian pertanyaan.

Pohon keputusan terdiri dari 3 jenis node:

a. Node keputusan - umumnya diwakili oleh kotak

b. Node kesempatan - umumnya diwakili oleh lingkaran

c. Node akhir - umumnya diwakili oleh segitiga

Sebagai alat pendukung keputusan, pohon keputusan dapat memberikan keputusan yang efektif karena mempunyai beberapa keuntungan seperti:

a Mudah untuk dipahami dan ditafsirkan.

b Memiliki nilai walau hanya dengan data yang sedikit.

c Dapat dipadukan dengan teknik pengambilan keputusan lainnya.

d Membentangkan semua masalah sehingga semua kemungkinan dapat diklasifikasikan.

e Memungkinkan untuk menganalisa dalam mengambil keputusan mengenai kemungkinan dari alternatif.

f Menyediakan suatu kerangka kerja untuk mengukur hasil dari nilai dan kemungkinan untuk mencapai keputusan.

g Membantu untuk membuat keputusan yang terbaik berdasarkan informasi yang ada.

Proses pencarian dari pohon keputusan menggunakan Pencarian Algoritma Depth First Search (DFS), yaitu proses pencarian dilakukan dari suksesor akar (node awal) secara mendalam dalam setiap level dari yang paling kiri hingga yang paling akhir (dead-end) atau sampai goal ditemukan. Jika pada level yang terdalam (level tertinggi/dead-end) solusi belum ditemukan, maka pencarian akan dilanjutkan pada node sebelah kanan dan node yang kiri dihapus dari memori. Jika pada level yang paling dalam tidak ditemukan solusi, maka pencarian akan dilanjutkan pada level sebelumnya. Operasi semacam ini dikenal dengan sebutan backtracking. Demikian seterusnya sampai ditemukan solusi [6]. 


\subsection{Dempster Shafer}

Metode Dempster-Shafer pertama kali diperkenalkan oleh Dempster, yang melakukan percoban model ketidakpastian dengan range probabilitas sebagai probabilitas tunggal. Kemudian pada tahun 1976 Shafer mempublikasikan teori Dempster tersebut pada sebuah buku yang berjudul Mathematical Theory of Evident. Secara umum teori Dempster-Shafer ditulis dalam suatu interval [Belief, Plausibility]. Belief (Bel) adalah ukuran kekuatan evidence dalam mendukung suatu himpunan proposisi. Jika bernilai 0 (nol) maka mengindikasikan bahwa tidak ada evidence, dan jika bernilai 1 menunjukkan adanya kepastian. Menurut Giarratano dan Riley fungsi belief dapat diformulasikan sebagai persamaan 1.

$\operatorname{Bel}(X)=\sum_{Y \subseteq X} m(Y)$

Keterangan :

$\operatorname{Bel}(\mathrm{X}) \quad$ : Belief $(\mathrm{X})$

$\mathrm{m}(\mathrm{Y}) \quad: \mathrm{m}(\mathrm{Y})=$ mass function $\operatorname{dari}(\mathrm{Y})$

Sedangkan Plausibility (Pls) dinotasikan pada persamaan 2.

$\operatorname{Pls}(X)=1-\operatorname{Bel}\left(X^{\prime}\right)=1-\sum_{Y \subseteq X^{\prime}} m\left(X^{\prime}\right)$

Keterangan :

Bel (X) : Belief $(\mathrm{X})$

Pls (X) : Plausibility $(\mathrm{X})$

$\mathrm{m}(\mathrm{X}) \quad$ : mass function dari $(\mathrm{X})$

$\mathrm{m}(\mathrm{Y}) \quad$ : mass function dari $(\mathrm{Y})$

Plausibility juga bernilai 0 sampai 1, jika kita yakin akan X' maka dapat dikatakan Belief $\left(\mathrm{X}^{\prime}\right)=1$ sehingga dari rumus di atas nilai Pls $(\mathrm{X})=0$. Beberapa kemungkinan range antara Belief dan Plausibility ditunjukkan oleh Tabel 1.

Tabel 1. Range Belief dan Plausibility [3]

\begin{tabular}{ll}
\hline Kemungkinan & Keterangan \\
\hline$[1,1]$ & Semua Benar \\
{$[0,0]$} & Semua Salah \\
{$[0,1]$} & Ketidakpastian \\
{$[\mathrm{Bel}, 1]$ where $0<\mathrm{Bel}<1$} & Cenderung Mendukung \\
{$[0, \mathrm{Pls}]$ where $0<\mathrm{Pls}<1$} & Cenderung Menolak \\
{$[$ Bel,Pls $]$ where $0<\mathrm{Bel} \leq \mathrm{Pls}<1$} & Cenderung Mendukung dan Menolak \\
\hline
\end{tabular}

Pada teori Dempster-Shafer juga dikenal adanya frame of discernment (FOD) yang dinotasikan dengan $\Theta$. FOD ini merupakan semesta pembicaraan dari sekumpulan hipotesis sehingga sering disebut dengan environment (O'Neill, 2000), seperti terlihat pada persamaan 2.3

$\Theta=\{\theta 1, \theta 2, \ldots \ldots \theta n\}$

Keterangan :

$\Theta$ : FOD atau environment, $\theta 1 \ldots . .0 n=$ elemen/unsur bagian dalam environment.

Environment mengandung elemen-elemen yang menggambarkan kemungkinan sebagai jawaban dan hanya ada satu yang akan sesuai dengan jawaban yang dibutuhkan. Kemungkinan ini dalam teori Dempster-Shafer disebut dengan power set dan dinotasikan dengan $\mathrm{P}(\theta)$, setiap elemen dalam power set ini memiliki nilai interval antara 0 sampai 1 , dinotasikan pada persamaan 4.

$\mathrm{m}=\mathrm{P}(\theta)$

keterangan :

$\mathrm{m} \quad$ : mass function

$\mathrm{P}(\theta) \quad$ : power set

sehingga dapat dirumuskan pada persamaan 5 . 
$\sum_{X \in P(\Theta)} m(X)=1 \approx \sum_{X \in P(\theta)} m(X)=1$

Keterangan :

$\mathrm{P}(\theta) \quad$ : power set

$\mathrm{m}(\mathrm{X}) \quad$ : mass function dari (X).

Mass function (m) dalam teori Dempster-Shafer adalah tingkat kepercayaan dari suatu evidence (jumlah jawaban benar), sering disebut dengan evidence measure sehingga dinotasikan dengan (m). nilai (m) tidak hanya mendefinikan elemen $\theta$ saja, namun juga semua subset-nya, sehingga ditunjukkan bahwa semua $(\mathrm{m})$ dalam subset $\theta$ sama dengan 1 . Apabila ada informasi hipotesis maka $\mathrm{m}\{\theta\}=1-(\mathrm{m})$ dan apabila tidak ada informasi apapun untuk memilih hipotesis tersebut, maka nilai $\operatorname{m}\{\theta\}=1,0$.

Pada aplikasi sistem pakar terdapat sejumlah evidence yang akan digunakan pada faktor ketidakpastian dalam pengambilan keputusan. Untuk mengatasi sejumlah evidence tersebut pada teori tersebut menggunakan aturan yang lebih dikenal dengan Dempster's Rule of Combination, seperti pada persamaan 6 .

$$
\left.m 1 \oplus m 2(Z)=\sum_{X \cap Y=Z} m 1(X) m 2(Y)\right)
$$

Keterangan :

$m 1 \oplus m 2(Z):$ mass function dari evidence $(\mathrm{Z})$

$m 1(X) \quad$ : mass function dari evidence $(\mathrm{X})$

$m 2(Y) \quad:$ mass function dari evidence $(\mathrm{Y})$

$\oplus \quad$ : operator direct sum

Secara umum formulasi untuk Dempster's Rule of Combination ditunjukkan dengan persamaan 7.

$m 1 \oplus m 2(Z)=\frac{\sum_{X \cap Y=Z} m 1(X) m 2(Y)}{1-k}$

keterangan :

$\mathrm{k}$ : jumlah evidential conflict.

Besarnya jumlah evidential conflict $(\mathrm{k})$ dirumuskan dengan:

$k=\sum_{X \cap Y=\phi} m 1(X) m 2(Y)$

Sehingga bila persamaan (8) disubstitusikan ke persamaan (9) akan menjadi persamaan 10

$m 1 \oplus m 2(Z)=\frac{\sum_{X \cap Y=Z} m 1(X) \cdot m 2(Y)}{1-\sum_{X \cap Y=\phi} m 1(X) \cdot m 2(Y)}$

Keterangan :

$m 1 \oplus m 2(Z):$ mass function dari evidence $(\mathrm{Z})$

$m 1(X) \quad$ : mass function dari evidence $(\mathrm{X})$

$m 2(Y) \quad:$ mass function dari evidence $(\mathrm{Y})$

Fungsi kombinasi m1 dan m2 sebagai m3 dirumuskan dengan persamaan 10.

$m 3(Z)=\frac{\sum_{X \cap Y=Z} m 1(X) \cdot m 2(Y)}{1-\sum_{X \cap Y=\phi} m 1(X) \cdot m 2(Y)}$ 
Keterangan :

$m 3(Z) \quad:$ mass function dari evidence $(\mathrm{Z})$

$m 1(X) \quad$ : mass function dari evidence $(\mathrm{X})$

$m 2(Y) \quad$ : mass function dari evidence $(\mathrm{Y})$

Munculnya mass function (m) baru dalam metode Dempster-Shafer dirumuskan dengan persamaan 11.

$m_{(n)}(Z)=\frac{\sum_{X \cap Y=Z} m_{n}(X) \cdot m_{n}(Y)}{1-\sum_{X \cap Y=\phi} m_{n}(X) \cdot m_{n}(Y)}$

Keterangan :

$$
\begin{array}{ll}
m_{n}(Z) & : \text { mass function dari evidence }(\mathrm{Z}) \\
m_{n}(X) & : \text { mass function dari evidence }(\mathrm{X}) \\
m_{n}(Y) & : \text { mass function dari evidence }(\mathrm{Y})
\end{array}
$$

\subsection{Penyakit Kehamilan}

Penyakit kehamilan adalah sebuah keluhan atau gangguan yang dirasakan dan terjadi pada saat kehamilan. Berdasarkan penjelasan dan pengalaman pakar, dalam penelitian ini penyakit kehamilan yang dilakukan diagnosa dipilih 13 penyakit, dengan alasan 13 penyakit yang diteliti adalah penyakit yang prosentasenya sering dialami oleh ibu hamil pada saat kehamilannya. Penyakit kehamilan trimester pertama dan trimester kedua atau umur kehamilan kurang dari 7 bulan meliputi hamil normal, ISK (Infeksi saluran kencing) dan gastritis (maag), kegawatan Obstetri merupakan keadaan yang mengancam nyawa selama kehamilan atau mendekati cukup bulan, meliputi perdarahan yang terjadi pada minggu awal kehamilan (abortus, hamil anggur, hamil ekstrauteri(ektopik) terganggu) dan perdarahan pada minggu akhir kehamilan, selama persalinan, dan pasca persalinan (Plasenta previa, Solusio (abrupsio) plasenta, Preeklamsia berat, Ruptur uteri, Retensio plasenta (plasenta inkompletus), Perdarahan pasca persalinan, Syok hemoragik, Syok septic (bakteri,endotoksin) [1].

\section{METODOLOGI}

Dalam Sistem Pakar ini data yang disiapkan berupa informasi gejala dari penyakit kehamilan serta kemungkinan penyakit kehamilan yang di teridentifikasi, yang didapat dari hasil wawancara langsung dengan pasien dan dari data rekam medis, sedangkan data Penyakit didapatkan dari Pakar dan literature.

\subsection{Prosedur Penelitian}

Prosedur Penelitian dimulai dengan identifikasi masalah kemudian Prosedur tahap berikutnya adalah pencarian sumber pengetahuan dilanjutkan dengan akuisisi pengetahuan dan dan representasi pegetahuan kemudian perancangan dan analisi, penelitian ditampilkan pada Gambar 1.

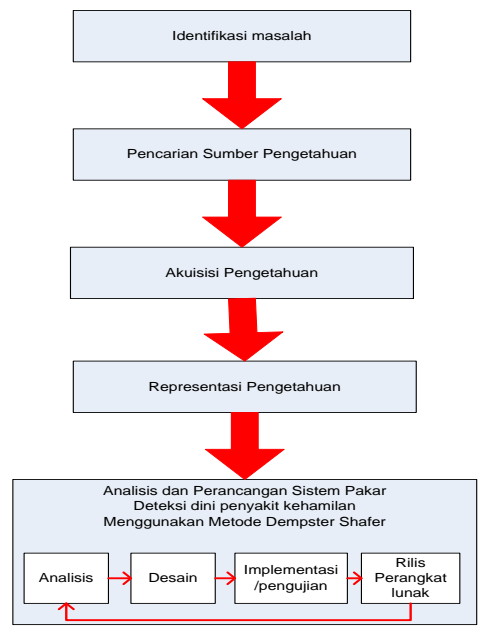

Gambar 1. Prosedur Penelitian 


\subsection{Pencarian Sumber Pengetahuan}

Tahapan pencarian sumber pengetahuan dilakukan melalui studi literatur dan konsultasi dengan pakar Obsgin di Rumah sakit Umum Dokter Soedarso Pontianak dr. Tri Wahyudi SPOG (Kobsos)

\subsection{Akuisisi Pengetahuan}

Akuisisi merupakan kegiatan penyerapan pengetahuan dari domain expert dilakukan dengan metode diskusi bebas (talk through) kepada ahli (pakar) dan studi pustaka terkait. Dari hasil akusisi pengetahuan diperoleh pengetahuan tentang Gejala-gejala, penyakit dan metode Dempster-Shafer, Setelah didapatkan pengetahuan-pengetahuan yang penting dalam penelitian ini selanjutnya menggali pengetahuanpengetahuan tersebut lebih dalam. Pengetahuan yang digali pada tahapan akuisisi pengetahuan melingkupi pengetahuan yang dapat menjadi dasar dalam melakukan penelitian. Pengetahuan tersebut diantaranya adalah pengetahuan mengenai gejala yang ada, penyakit, teknik perhitungan dengan metode Dempster-Shafer

\subsection{Representasi Pengetahuan}

Untuk menghasilkan sistem pakar penyakit kehamilan pada manusia yang baik diperlukan pembuatan basis pengetahuan dan basis aturan yang lengkap dan baik agar proses inferensi berjalan dengan baik.

\subsection{Basis Pengetahuan}

Dari pengetahuan berupa gejala dan penyakit kehamilan pada ibu hamil, maka dapat dibuat basis pengetahuan berupa hubungan atau keterkaitan yang ada antara gejala dan penyakit kehamilan pada ibu hamil. Basis pengetahuan tersebut dapat dilihat pada tabel 2.

Tabel 2. Tabel keputusan penyakit (basis pengetahuan)

\begin{tabular}{|c|c|c|c|c|c|c|c|c|c|c|c|c|c|c|c|}
\hline \multirow{2}{*}{ No } & \multirow{2}{*}{ Gejala } & \multirow{2}{*}{$\begin{array}{c}\text { Kode } \\
\text { Gejala }\end{array}$} & \multirow{2}{*}{$\begin{array}{c}P 01 \\
H N\end{array}$} & \multirow{2}{*}{$\begin{array}{l}P 02 \\
I S K\end{array}$} & \multirow{2}{*}{$\begin{array}{c}P 03 \\
M G\end{array}$} & \multirow{2}{*}{$\begin{array}{r}P 04 \\
A B\end{array}$} & \multirow{2}{*}{$\begin{array}{c}P 05 \\
H A\end{array}$} & \multirow{2}{*}{$\begin{array}{r}P 06 \\
H E\end{array}$} & \multirow{2}{*}{$\begin{array}{r}P 07 \\
P P\end{array}$} & \multirow{2}{*}{$\begin{array}{r}P 08 \\
S P\end{array}$} & \multirow{2}{*}{$\begin{array}{r}P 09 \\
P B\end{array}$} & \multirow{2}{*}{$\begin{array}{r}P 10 \\
R U\end{array}$} & \multirow{2}{*}{$\frac{P 11}{R P}$} & \multirow{2}{*}{$\begin{array}{r}P 12 \\
S H\end{array}$} & \multirow{2}{*}{$\begin{array}{r}P 13 \\
S S\end{array}$} \\
\hline & & & & & & & & & & & & & & & \\
\hline 1 & Tes Kehamilan $(+)$ & K01 & $*$ & $*$ & $*$ & $*$ & $*$ & $*$ & $*$ & $*$ & $*$ & $*$ & $*$ & $*$ & $*$ \\
\hline 2 & $\begin{array}{l}\text { Usia hamil } 7 \text { bulan / } \\
\text { lebih }\end{array}$ & K02 & & & & & & & $*$ & $*$ & & & & & \\
\hline 3 & Mual (nausea) & K03 & $*$ & & $*$ & & $*$ & $*$ & & & & & & & \\
\hline 4 & Muntah (emesis) & K04 & $*$ & & $*$ & & $*$ & $*$ & & & & & & & \\
\hline 5 & Kejang & K05 & & & & & & & & & $*$ & & & & \\
\hline 6 & $\begin{array}{l}\text { Proteinuria, lebih } \\
\text { dari } 3 \mathrm{~kg} / \mathrm{liter}\end{array}$ & K06 & & & & & & & & & $*$ & & & & \\
\hline 7 & $\begin{array}{l}\text { Tekanan darah >= } \\
160 / 110 \mathrm{mmHg}\end{array}$ & K07 & & & & & & & & & $*$ & & & & \\
\hline 8 & Pusing & K08 & $*$ & & & & & & & & $*$ & & & & \\
\hline 9 & Nyeri Ulu hati & K09 & $*$ & & $*$ & & & & & & $*$ & & & & \\
\hline 10 & Kembung & K10 & $*$ & & $*$ & & & & & & & & & & \\
\hline 11 & Sering kencing & K11 & & $*$ & & & & & & & & & & & \\
\hline 12 & $\begin{array}{l}\text { Nyeri perut bagian } \\
\text { bawah }\end{array}$ & K12 & & $*$ & & $*$ & & $*$ & & & & $*$ & & & \\
\hline 13 & Nyeri waktu kencing & K13 & & $*$ & & & & & & & & & & & \\
\hline 14 & Nyeri pinggan & K14 & & $*$ & & & & & & & & & & & \\
\hline 15 & $\begin{array}{l}\text { Nyeri perut pada } \\
\text { satu sisi kanan/kiri }\end{array}$ & K15 & & & & $*$ & & $*$ & & & & & & & \\
\hline 16 & Nyeri hebat tiba-tiba & K16 & & & & & & $*$ & & & & & & & \\
\hline 17 & $\begin{array}{l}\text { Pendarahan pada } \\
\text { jalan lahir }\end{array}$ & K17 & & & & $*$ & $*$ & $*$ & & & & $*$ & $*$ & $*$ & \\
\hline 18 & $\begin{array}{l}\text { Pendarahan pada } \\
\text { jalan lahir warna } \\
\text { merah }\end{array}$ & K18 & & & & & & & $*$ & & & & & & \\
\hline
\end{tabular}


Jurnal SIMETRIS, Vol 7 No 1 April 2016

ISSN: 2252-4983

\begin{tabular}{|c|c|c|c|c|c|c|c|c|c|c|c|c|c|c|c|}
\hline $\mathrm{No}$ & Geiala & Kode & $P 01$ & $P 02$ & $P 03$ & $P 04$ & P05 & P06 & $P 07$ & $P 08$ & $P 09$ & $P 10$ & $P 11$ & $P 12$ & $P 13$ \\
\hline NoO & Gejauta & Gejala & $H N$ & ISK & $M G$ & $A B$ & $H A$ & $H E$ & $P P$ & $S P$ & $P B$ & $R U$ & $R P$ & SH & $S S$ \\
\hline 19 & $\begin{array}{l}\text { Pendarahan pada } \\
\text { jalan lahir warna } \\
\text { kehitaman }\end{array}$ & K19 & & & & & & & & $*$ & & & & & \\
\hline 20 & Kematian janin & K20 & & & & $*$ & & $*$ & $*$ & $*$ & $*$ & $*$ & & & \\
\hline 21 & $\begin{array}{l}\text { Keluar gelembung } \\
\text { seperti buah anggur } \\
\text { dari }\end{array}$ & K21 & & & & & $*$ & & & & & & & & \\
\hline 22 & syok & K22 & & & & & & $*$ & $*$ & $*$ & & $*$ & $*$ & $*$ & $*$ \\
\hline 23 & $\begin{array}{l}\text { Pada pemeriksaan } \\
\text { dinding rahim, } \\
\text { bagian }\end{array}$ & K23 & & & & & & & & & & $*$ & & & \\
\hline 24 & $\begin{array}{l}\text { Tampak plasenta } \\
\text { atau tali pusat di } \\
\text { jalan lahir }\end{array}$ & K24 & & & & & & & & & & & $*$ & & \\
\hline 25 & $\begin{array}{l}\text { Kontraksi rahim } \\
\text { lemah }\end{array}$ & K25 & & & & & & & & & & & $*$ & & \\
\hline 26 & $\begin{array}{l}\text { Kontraksi lemah } \\
\text { pasca melahirkan }\end{array}$ & K26 & & & & & & & & & & & & $*$ & \\
\hline 27 & Pasien tampak pucat & K27 & & & & & & & $*$ & $*$ & & $*$ & $*$ & $*$ & \\
\hline 28 & $\begin{array}{l}\text { Air kencing } \\
\text { berwarna kemerahan }\end{array}$ & K28 & & & & & & & & & & $*$ & & & \\
\hline 29 & $\begin{array}{l}\text { Terdapat sisa } \\
\text { plasenta }\end{array}$ & K29 & & & & & & & & & & & $*$ & & \\
\hline 30 & $\begin{array}{l}\text { Tekanan darah turun } \\
\text { sampai dibawah } \\
90 / 60\end{array}$ & K30 & & & & & & & $*$ & $*$ & & $*$ & $*$ & $*$ & \\
\hline 31 & $\begin{array}{l}\text { Nadi cepat dan } \\
\text { teraba kecil }\end{array}$ & K31 & & & & & & & $*$ & $*$ & & $*$ & $*$ & $*$ & $*$ \\
\hline 32 & $\begin{array}{l}\text { Tidak mengalami } \\
\text { nyeri perut }\end{array}$ & K32 & & & & & & & $*$ & & & & & & \\
\hline 33 & $\begin{array}{l}\text { Jumlah pendarahan } \\
\text { banyak }\end{array}$ & K33 & & & & & & & $*$ & & & & & & \\
\hline 34 & kontraksi dari rahim & K34 & & & & & & & & $*$ & & & & & \\
\hline 35 & $\begin{array}{l}\text { jumlah pendarahan } \\
\text { sedikit }\end{array}$ & K35 & & & & & & & & $*$ & & & & & \\
\hline 36 & Produksi urin sedikit & K36 & & & & & & & & & $*$ & $*$ & $*$ & $*$ & $*$ \\
\hline 37 & $\begin{array}{l}\text { Kontraksi rahim } \\
\text { yang hilang }\end{array}$ & K37 & & & & & & & & & & $*$ & & & \\
\hline 38 & Kesadaran menurun & K38 & & & & & & & & & & $*$ & & $*$ & $*$ \\
\hline 39 & Demam tinggi & K39 & & & & & & & & & & & & & * \\
\hline
\end{tabular}

\subsection{Basis Aturan}

Basis aturan diambil dari basis pengetahuan yang ada kemudian disusun dalam bentuk aturan (rule). Aturan (rule) tersebut dapat dilihat pada tabel 3. 
Tabel 3. Aturan (rule)

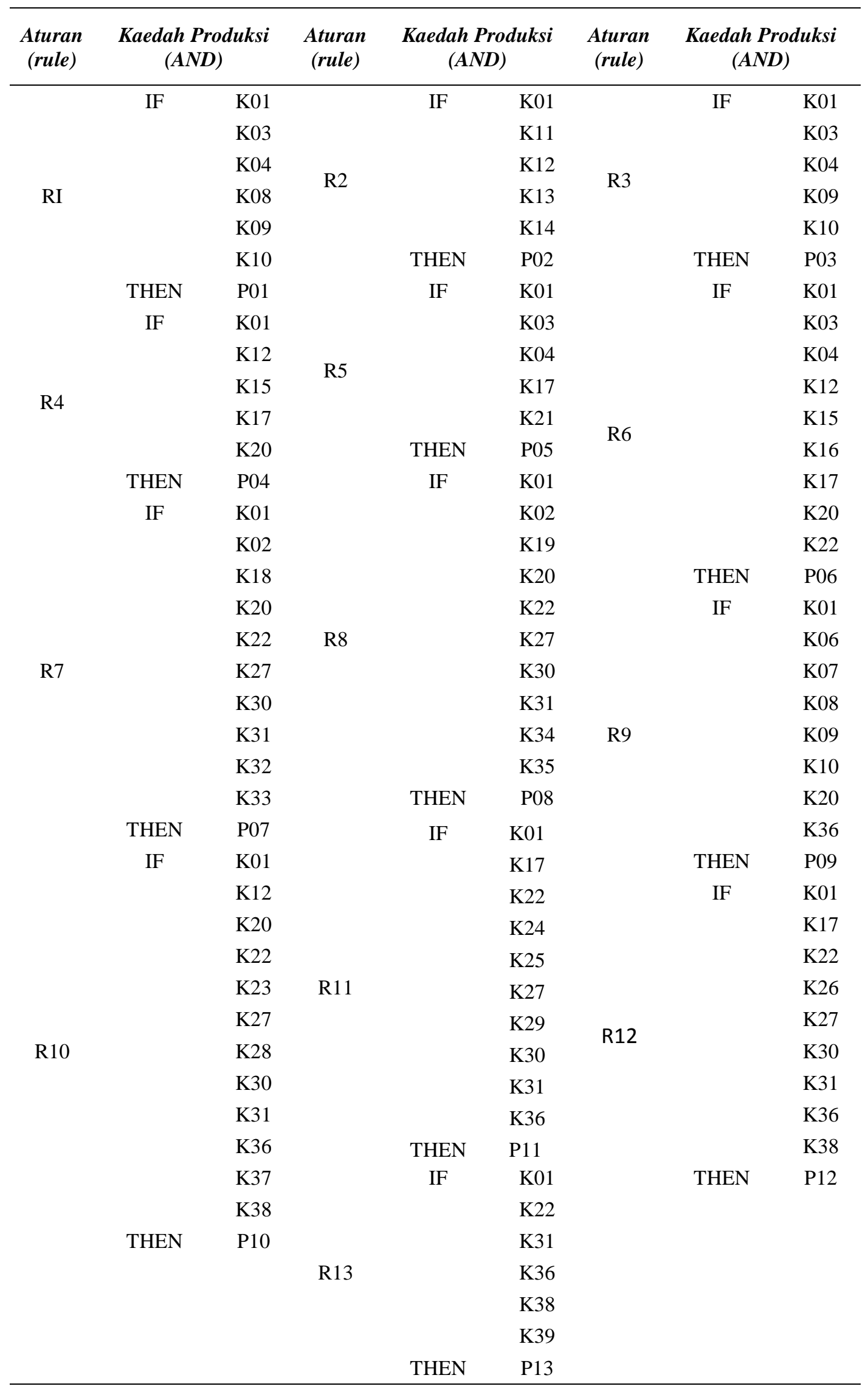


Dari tabel aturan yang telah didapat, maka dapat terbentuk suatu decision tree. Decision tree berfungsi sebagai alat pendukung keputusan sebagai acuan penulurusan penyakit dari gejala yang timbul. Sebuah decision tree dapat dianggap sebagai suatu semantic network hirarki yang diikat oleh serangkaian aturan (rule). Tree ini mirip dengan pohon keputusan yang digunakan pada teori keputusan. Tree dibentuk oleh simpul (node) yang mempresentasikan tujuan (goal) dan hubungan (link) yang dapat mempresentasikan keputusan (decision). Akar (root) dari pohon berada disebelah kiri dan daun (leaves) berada di sebalah kanan. Keuntungan utama dari decision tree yaitu tree dapat menyederhanakan proses akuisi pengetahuan.

Tree yang digunakan pada penelitian ini merupakan suatu forward chaining tree. Hal tersebut berkaitan dengan masalah diagnosis yang dibahas dalam penelitian sistem pakar pada diagnosa penyakit kehamilan. Pada forward chaining tree penelusuran informasi dilakukan secara forward (kedepan) seperti yang umumnya digunakan pada masalah-masalah diagnosis lainnya. Dari pernyakit kehamilan yang diketahui, kemudian mencoba melakukan penelusuran ke depan untuk mencari fakta-fakta yang cocok berupa gejala-gejala penyebab penyakit kehamilan yang bersangkutan. Pada tree tersebut dapat dilihat bagaimana suatu gejala penyakit atau kesimpulan gejala penyakit merujuk kepada suatu jenis penyakit tertentu, dan bagaimana beberapa gejala yang sama dapat merujuk kepada beberapa penyakit yang berbeda. Pada penelusuran dengan metode forward chaining dapat dilihat bahwa penelusuran kedepan untuk mengenali penyebab dan jenis penyakit yang dialami oleh pasien. Perhatikan pada gambar 2.

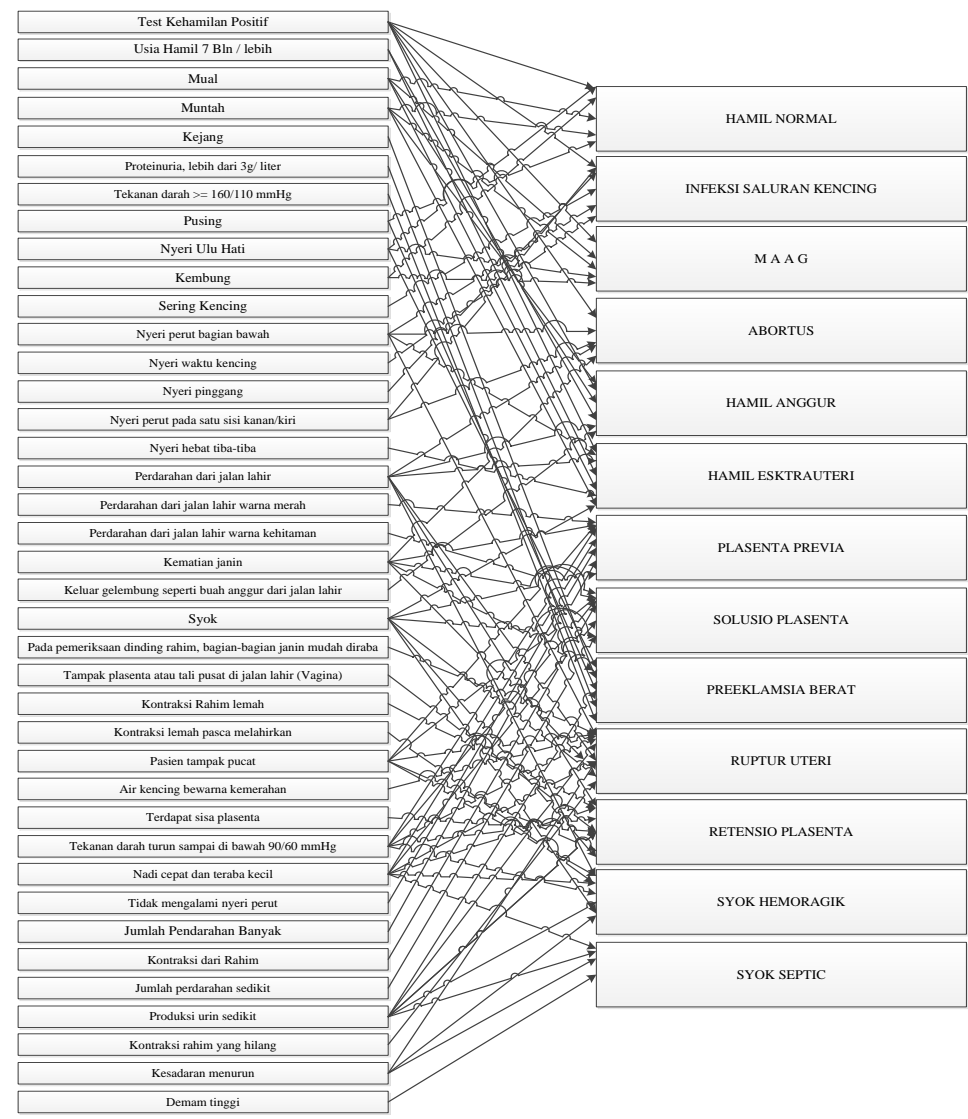

Gambar 2. Decision Tree dengan metode Forward Chaning

\subsection{Mencari Data Nilai Gejala}

Nilai Gejala adalah ukuran probabilitas penyakit, nilai ini ditentukan melalui informasi dari literatur dan pengalaman pakar, dengan menggunakan kaidah probabilitas. Dari 13 penyakit, mual mempunyai kemungkinan sebagai hamil normal (HN), maag(MG), hamil anggur (HA) dan hamil ekstrauteri (HE) maka perhitungan probabilitas gejala menggunakan persamaan 12 .

$$
\mathrm{P}(\mathrm{X} \mid \mathrm{Y})=\frac{\mathrm{P}(\mathrm{X} \cap \mathrm{Y})}{\mathrm{P}(\mathrm{Y})}
$$


a Langkah I.

Menghitung probabilitas gejala P03 dengan menggunakan persamaan 12. Dari lampiran II , diketahui bahwa penyakit yang mengalami gejala P03 adalah penyakit HN(P01), MG(P03), $\mathrm{HA}(\mathrm{P} 05), \mathrm{HE}(\mathrm{P} 06)$ maka probabilitas untuk penyakit

Gejala P3 mual

P(Mual|HN,MG,HA,HE)

$\mathrm{P}($ Mual $\mid \mathrm{HN})=8 / 11=0,72$

$\mathrm{P}($ Mual $\mid \mathrm{MG})=1 / 1=1$

$\mathrm{P}($ Mual $\mid \mathrm{HA})=1 / 1=1$

$\mathrm{P}($ Mual $\mid \mathrm{HE})=2 / 3=0,67$

$\mathrm{P}($ Mual $\mid \mathrm{HN}, \mathrm{MG}, \mathrm{HA}, \mathrm{HE})=0,72 \cdot 1 \cdot 1 \cdot 0,67=0,482$

Sehingga, nilai probabilitas gejala mual dengan penyakit HN,MG,HA,HE adalah mMual $(\mathrm{MG}, \mathrm{HA}, \mathrm{HE})=0,482$

b Langkah 2

Dari langkah 1, telah didapat nilai probabilitas kepastian untuk masing-masing gejala. Kemudian kita cari nilai nonkepastian yang dinotasikan dengan $\mathrm{m}(\boldsymbol{\Theta})$ dengan cara melakukan pengurangan dari nilai kepastian. lakukan pengurangan dari nilai kepastian untuk masing-masing gejala.

Gejala 1 (Hamil normal)

$\mathrm{m} 1(\mathrm{HN}, \mathrm{ISK}, \mathrm{MG}, \mathrm{AB}, \mathrm{HE}, \mathrm{HA})=1$

$\mathrm{m} 1(\Theta)=1-\mathrm{m} 1(\mathrm{HN}, \mathrm{ISK}, \mathrm{MG}, \mathrm{AB}, \mathrm{HE}, \mathrm{HA})$ (nilai kepastian gejala dengan penyakit $\mathrm{HN}, \mathrm{ISK}, \mathrm{MG}$, $\mathrm{AB}, \mathrm{HE}, \mathrm{HA})$

$=1-1=0$ (nilai ketidakpastian)

Kemudian dihitung dengan rumus Dempster's Rule of Combination yang dirumuskan pada persamaan 10

\subsection{Perancangan Sistem Pakar Dengan Metode Dempster-Shafer}

\subsubsection{Perancangan DFD (Data Flow Diagram)}

Data flow diagram merupakan diagram aliran data yang menggambarkan bagaimana data diproses oleh sistem. Selain itu Data flow diagram (DFD) menggambarkan notasi- notasi aliran data di dalam system yang dapat dilihat pada gambar 3 .

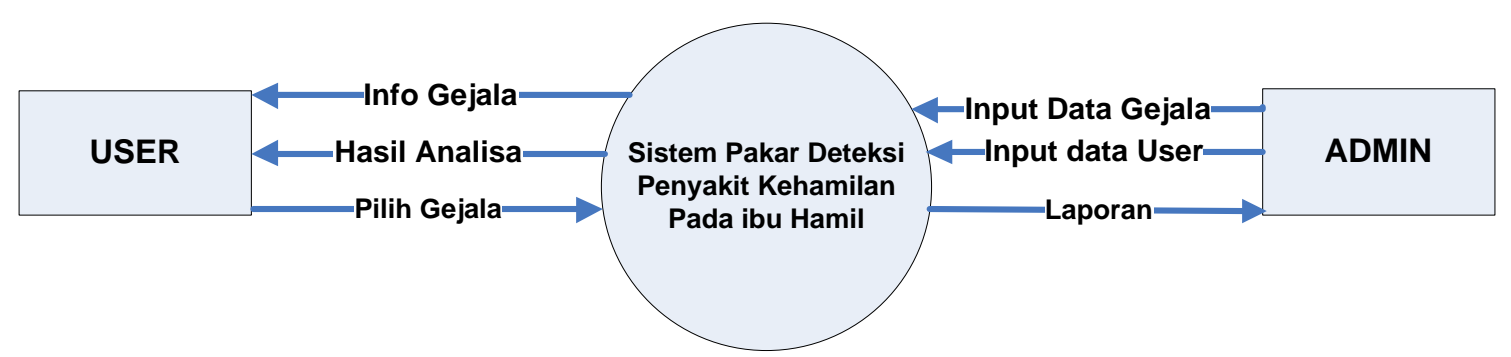

Gambar 3. Data Flow Diagram Sistem Pakar

\subsubsection{Perancangan Mesin Inferensi}

Dalam perancangan sistem pakar ini menggunakan metode penalaran forward chaining (pelacakan maju) yaitu dimulai dari sekumpulan fakta-fakta tentang suatu gejala yang diberikan oleh user sebagai masukan ke dalam sistem, kemudian dilakukan perhitungan sampai tujuan akhir berupa diagnosa penyakit kehamilan yang dialami dan nilai kepercayaannya, flowchart (diagram alir) menggunakan metode Dempster-shafer ditampilkan pada gambar 4 


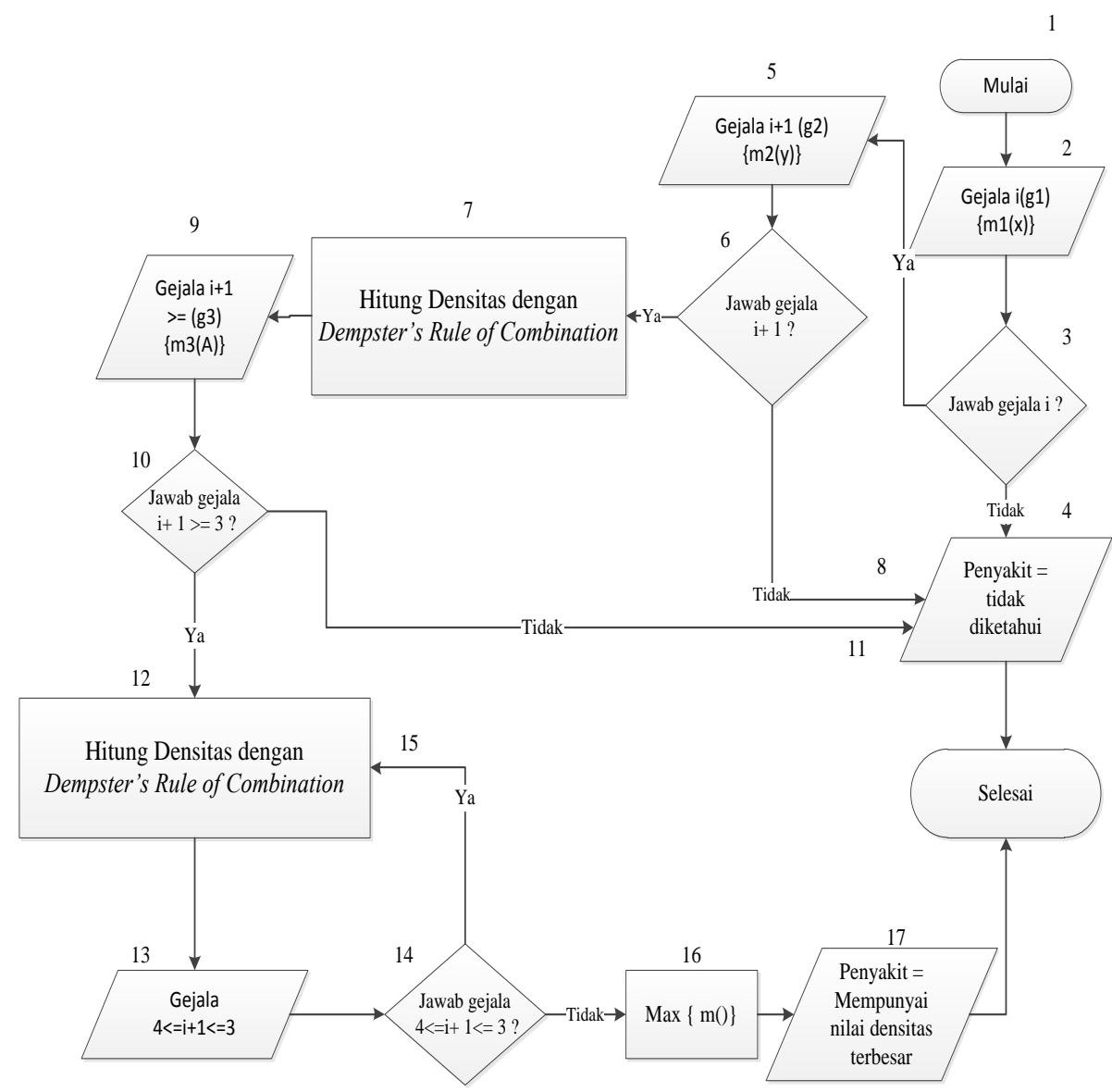

Gambar 4. Flowchart Metode Dempster Shafer

Dari mesin inferensi tersebut selanjutnya dilakukan perhitungan metode Dempster-Shafer berdasarkan gejala dengan bobot yang ada menggunakan matrik, kemudian dihitung densitasnya menggunakan rumus aturan kombinasi Dempster-Shafer dengan mengacu pada persamaan 9 dan persamaan 10. Adapun perhitungan metodenya adalah sebagai berikut : Andaikan seorang pasien mengalami 3 gejala yaitu Kehamilan positif (K01), sering kencing (K11), nyeri perut bagian bawah (K12)

$\Theta \quad=\{\mathrm{HN}, \mathrm{ISK}, \mathrm{MG}, \mathrm{AB}, \mathrm{HA}, \mathrm{HE}\}$

dimana: $\quad \mathrm{HN}=$ Hamil normal

ISK = Infeksi Saluran Kencing

$\mathrm{MG}=$ Maag gaatritis

$\mathrm{AB}=$ Abortus

$\mathrm{HA}=$ Hamil anggur

$\mathrm{HE}=$ Hamil ekstrauteri terganggu

$$
\begin{gathered}
m 5\{\mathrm{ISK}\}=\quad \frac{0,11+0,89}{1-0}=1 \\
m 5\{\mathrm{ISK}, \mathrm{AB}, \mathrm{HE}, \mathrm{RU}\}=\frac{0}{1-0}=0 \\
m 5\{\Theta\}=\quad \frac{0}{1-0}=0
\end{gathered}
$$

1. Kehamilan Positif dengan nilai probabilitas 1 . Gejala tersebut adalah gejala dari Hamil normal (HN), ISK (Infeksi saluran kencing), Maag (MG), AB (Abortus), Hamil Anggur (HA), Hamil Ekstra Uretri (HE)

$m 1(\mathrm{HN}, \mathrm{ISK}, \mathrm{MG}, \mathrm{AB}, \mathrm{HA}, \mathrm{HE})=1$

$m 1(\Theta)=1-1=0$

2. Sering kencing dengan nilai probabilitas 0,48 . Gejala tersebut adalah gejala dari penyakit Infeksi saluran kencing (ISK)

$m 2($ ISK $)=1$

$m 2(\Theta)=1-1=0$

Dengan munculnya gejala kedua yaitu sering kencing, maka harus dilakukan penghitungan densitas baru untuk beberapa kombinasi (m3). Untuk memudahkan perhitungan maka himpunan-himpunan bagian yang terbentuk dimasukkan ke dalam tabel. Kolom pertama diisi dengan gejala yang pertama $(\mathrm{m} 1)$. 
Sedangkan baris pertama diisi dengan gejala yang kedua (m2). Sehingga diperoleh nilai m3 sebagai hasil kombinasi $\mathrm{m} 1$ dan $\mathrm{m} 2$ terlihat pada tabel 4 .

Tabel 4 Aturan Kombinasi m3

\begin{tabular}{|c|c|c|}
\hline & $\mathbf{m} \mathbf{2}($ ISK) $=\mathbf{1}$ & $\mathrm{m} 2(\Theta)=0$ \\
\hline $\begin{array}{c}\text { m1(HN, ISK, } \\
\mathrm{HE} \text { ) }=1\end{array}$ & $\mathrm{~m} 1 \oplus \mathrm{m} 2$ (ISK) $=1$ & $\begin{array}{c}\mathrm{m} 1 \oplus \mathrm{m} 2(\mathrm{HN}, \mathrm{ISK}, \mathrm{AB}, \\
\mathrm{MG}, \mathrm{HA}, \mathrm{HE})=0\end{array}$ \\
\hline $\mathrm{m} 1(\Theta)=0$ & $\mathrm{~m} 1 \oplus \mathrm{m} 2$ (ISK) $=0$ & $\mathrm{ml} \oplus \mathrm{m} 2(\Theta)=0$ \\
\hline
\end{tabular}

Apabila pasien merasakan gejala 3

$$
\begin{array}{ccc}
m 3(\text { ISK })= & \frac{1+0}{1-0}=1 \\
m 3(\mathrm{HN}, \mathrm{ISK}, \mathrm{MG}, \mathrm{AB}, & \frac{0}{1-0}=0 \\
\mathrm{HA}, \mathrm{HE})= & \frac{0}{1-0}=0
\end{array}
$$

3. Nyeri perut bagian bawah

Dengan nilai probabilitas 0,11 . Gejala tersebut adalah gejala dari penyakit ISK, AB, HE, RU

\begin{tabular}{|c|c|c|c|}
\hline & \multicolumn{2}{|c|}{$\begin{array}{c}\text { m4(ISK, AB, HE, RU) } \\
=0,11\end{array}$} & $\mathrm{~m} 4(\Theta)=0,89$ \\
\hline $\mathbf{m} 3($ ISK $)=1$ & \multicolumn{2}{|c|}{$\mathrm{m} 3 \oplus \mathrm{m} 4(\mathrm{ISK})=0,11$} & $\mathrm{~m} 3 \oplus \mathrm{m} 4(\mathrm{ISK})=0,89$ \\
\hline$m 3(\Theta)=0$ & \multicolumn{2}{|c|}{$\begin{array}{c}\mathrm{m} 3 \oplus \mathrm{m} 4(\mathrm{ISK}, \mathrm{AB}, \mathrm{HE}, \\
\mathrm{RU})=0\end{array}$} & $\mathrm{~m} 3 \oplus \mathrm{m} 4(\Theta)=0$ \\
\hline \multicolumn{2}{|c|}{$m 5\{\mathrm{ISK}\}=$} & $\frac{0,11+0,89}{1-0}$ & $=1$ \\
\hline \multicolumn{2}{|c|}{$m 5\{$ ISK, $\mathrm{AB}, \mathrm{HE}, \mathrm{RU}\}=$} & $\frac{0}{1-0}$ & $=0$ \\
\hline \multicolumn{2}{|c|}{$m 5\{\Theta\}=$} & $\frac{0}{1-0}$ & $=0$ \\
\hline
\end{tabular}

$m 4(\mathrm{ISK}, \mathrm{AB}, \mathrm{HE}, \mathrm{RU})=0,11$

$m 4(\Theta)=1-0,11=0,89$

Dengan munculnya gejala ketiga yaitu nyeri perut bagian bawah, maka harus dilakukan penghitungan densitas baru untuk beberapa kombinasi (m4). Sehingga diperoleh nilai m5 sebagai hasil kombinasi $\mathrm{m} 3$ dan $\mathrm{m} 4$ yang ditampilkan pada tabel 5.

Tabel 5. Aturan Kombinasi m5

Dengan munculnya gejala nyeri perut bagian bawah, maka nilai densitas yang paling besar adalah $m 5($ ISK $)=1$. Dari tiga gejala yang ada, maka kemungkinan diagnose penyakit adalah Infeksi saluran kencing (ISK) dengan nilai kepercayaan sebesar 1 atau 100\%

\subsubsection{Perancangan Tabel Basis Data}

Basis data ini dibuat dengan menggunakan MySQL. Dalam perencanaan sistem pakar ini terdapat 7 tabel utama untuk menyimpan data. Adapun relasi tabel ditampilkan pada Gambar 5. 


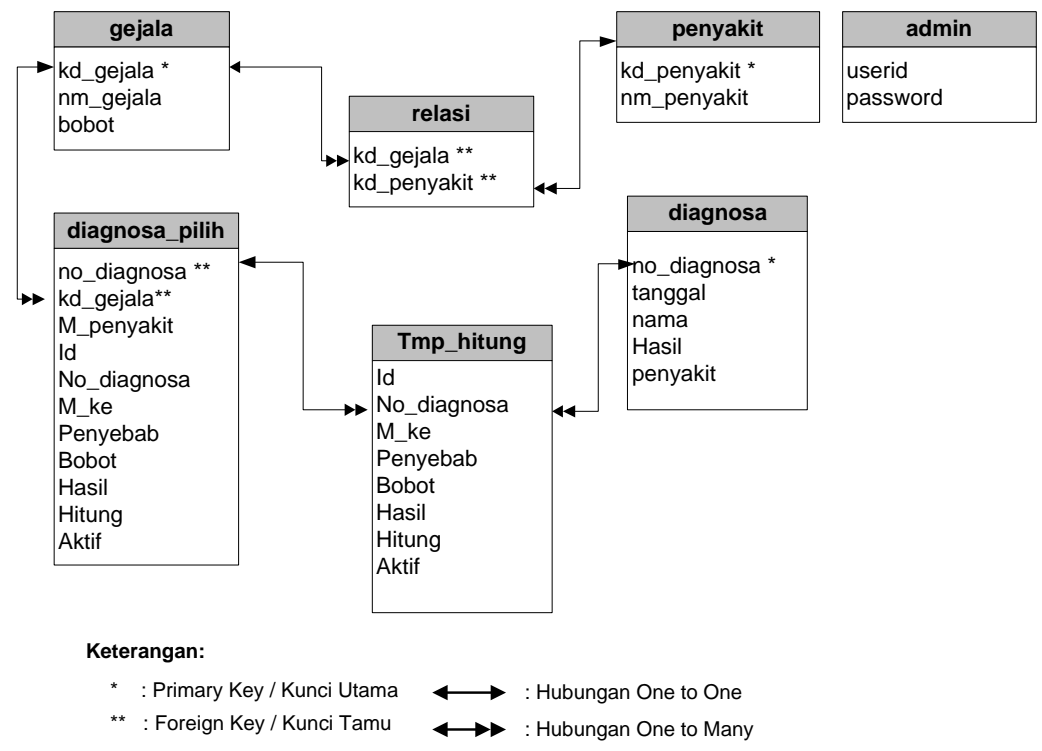

Gambar 5. Relasi Antar Tabel

\section{HASIL PENELITIAN DAN PEMBAHASAN}

\subsection{Hasil Penelitian}

Hasil dari penelitian ini adalah sebuah sistem pakar yang digunakan untuk diagnose penyakit kehamilan. Sistem pakar yang dihasilkan ini memiliki sebuah lingkungan konsultasi (consultation environment) (Turban, 1995) dalam bentuk antarmuka user yang dapat memudahkan pengguna awam dalam berkonsultasi dengan sistem. Antarmuka user terbagi menjadi dua, yaitu antarmuka user Admin dan antarmuka user pasien. Lingkungan konsultasi pada antarmuka user yang terdapat pada sistem pakar ini terdiri dari dua sesi, yaitu sesi konsultasi dan sesi hasil konsultasi. Sesi konsultasi merupakan sesi dimana pasien memilih gejala yang telah disediakan oleh sistem sedangkan sesi hasil konsultasi adalah hasil pengolahan data berupa diagnosa penyakit.

\subsection{Kerangka Sistem}

Sistem pakar deteksi dini penyakit kehamilan menggunakan metode dempster shafer ini merupakan sebuah sistem berbasis web disajikan dalam desktop yang menyajikan informasi tentang penyakit kehamilan dan probabilitas (densitas kepercayaan penyakit), Hasil dari sistem ini dapat dijadikan informasi awal pengguna sebagai rujukan ke dokter. Pada kerangka sistem ini dilakukan beberapa tahapan, yaitu Input, Proses dan output. Tahapan input dilakukan pemilihan gejala penyakit oleh user, dan Input, edit data gejala, penyakit dan basis aturan oleh admin.Pada tahapan proses sistem akan melakukan proses aturan sistem pakar yaitu basis pengetahuan, mesin inferensi dan perhitungan dengan menggunakan metode dempster shafer. Pada tahapan output user dapat melihat besaran nilai kepercayaan penyakit. Sedangkan admin dapat menampilkan laporan kesuluruhan diagnosa/ daftar diagnosa. Kerangka sistem pakar ini ditampilkan pada Gambar 6. 


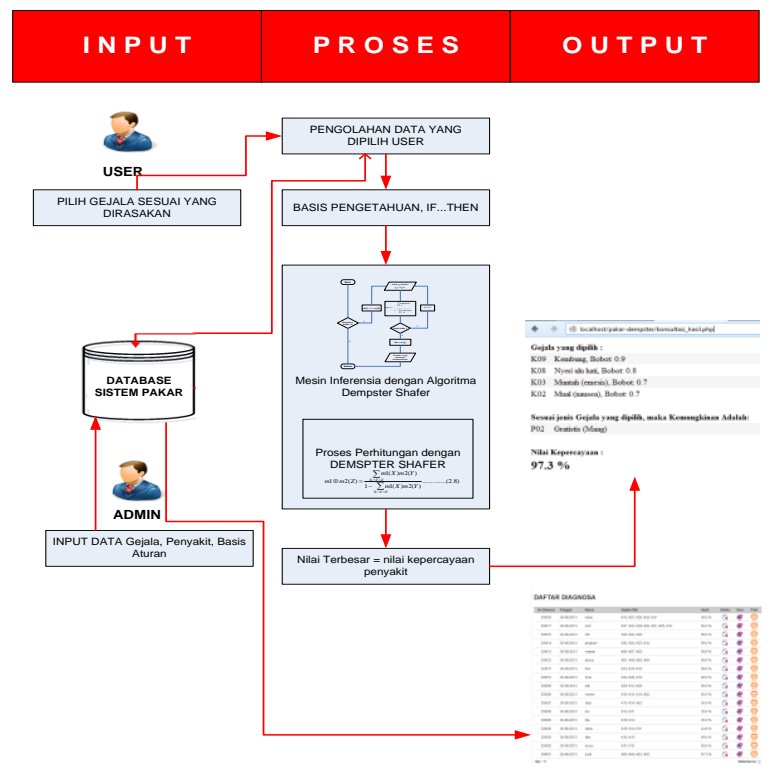

Gambar 6. Kerangka Sistem Pakar Diagnosa Penyakit Kehamilan

\subsection{Pembahasan}

\subsubsection{Deskripsi Sistem}

Sistem ini terbagi menjadi tiga tahapan yaitu input, proses dan output. Dalam tahapan input pengguna/pasien akan memilih gejala yang akan disimpan dalam data diagnosa, sistem akan menyesuaikan hasil input dengan aturan basis pengetahuan dan decision tree, kemudian dari hasil pilih gejala tersebut (input) data gejala akan di lakukan penghitungan dengan metode dempster shafer untuk mendapatkan nama penyakit dan nilai densitas dari penyakit tersebut untuk menetukan tingkat kepercayaan dari penyakit tersebut (proses), setelah itu akan menghasilkan output berupa nama penyakit dan nilai kepercayaan penyakit.

\subsubsection{Cara Pengujian Sistem}

Sistem pakar yang dihasilkan diuji terhadap data nyata dari obyek penelitian yaitu data rekam medik. Pengujian dilakukan sesuai dengan aturan sistem pakar kemudian dibandingkan hasilnya antara perhitungan manual dengan menggunakan sistem pakar. Pengujian sistem menggunakan 150 data rekam medik yang sudah ada hasil diagnosa dari pakar (dokter). Dari pengujian yang telah dilakukan yaitu perhitungan manual dengan menggunakan metode Dempster-Shafer dan pengujian pada sistem, diketahui bahwa hasil output yang dikeluarkan sistem telah mendekati kesesuaian dengan hasil diagnosa dokter.

\subsubsection{Analisa Data Input}

Aplikasi sistem pakar ini membutuhkan data input yang digunakan sebagai basis pengetahuan dari sistem dalam mendeteksi dini penyakit, inputan berupa :

a Data Gejala baru yang belum terdapat dalam sistem

b Data penyakit yang belum terdapat dalam sistem

c Data aturan ditambahkan sesuai dengan gejala dan penyakit yang muncul, pakar memberikan nilai densitas kepercayaan penyakit dari masing-masing gejala.

Proses inti dari sistem ini adalah proses penalaran untuk menentukan jenis penyakit yang diderita berdasarkan masukan dari user berdasarkan basis pengetahuan dan penelursuran penyakit.

\subsubsection{Analisa Data Output}

Data output yang dihasilkan adalah data hasil diagnosa berupa kemugkinan penyakit dan nilai persentase probabilitas kepercayaan penyakit berdasarkan metode Dempster-Shafer. 


\subsubsection{Hasil Pengujian}

Pengujian merupakan tahapan yang dilakukan untuk menguji sistem secara keseluruhan. Pada tahap ini dilakukan uji kesesuaian pada hasil diagnosa dan proses penerapan metode Dempste-Shafer.

1. Pengujian Diagnosa Berdasarkan Aturan (Rule)

Pada proses diagnosa, user memasukkan data keluhan/gejala berupa tes kehamilan positif (K01), sering kencing (K11), nyeri perut bagian bawah (K12) dan nyeri waktu kencing (K13), seperti terlihat pohon keputusan yaitu gambar 3. 5 dan tampilan hasil diagnosa pada gambar 4.5. maka akan dihasilkan diagnosa penyakit infeski saluran kencing (ISK) atau P02

2. Pengujian Diagnosa Dengan Memilih Satu Gejala

Apabila user memilih satu gejala dan tidak memilih gejala lain, misalkan user hanya memilih gejala yaitu kehamilan positif (K01), maka sistem belum dapat menyimpulkan penyakit. Berdasarkan production rule, apabila hanya ada satu gejala yaitu K01, maka sistem belum dapat menyimpulkan penyakit.

Dalam pengujian sistem ini menjelaskan mengenai hasil uji coba perangkat lunak Sistem pakar deteksi dini penyakit kehamilan menggunakan metode dempster-shafer. Selain itu, dari hasil uji coba yang telah dilakukan akan dianalisa apakah rancangan ini dapat memenuhi tujuan yang akan dicapai, ditunjukkan pada gambar 7 .

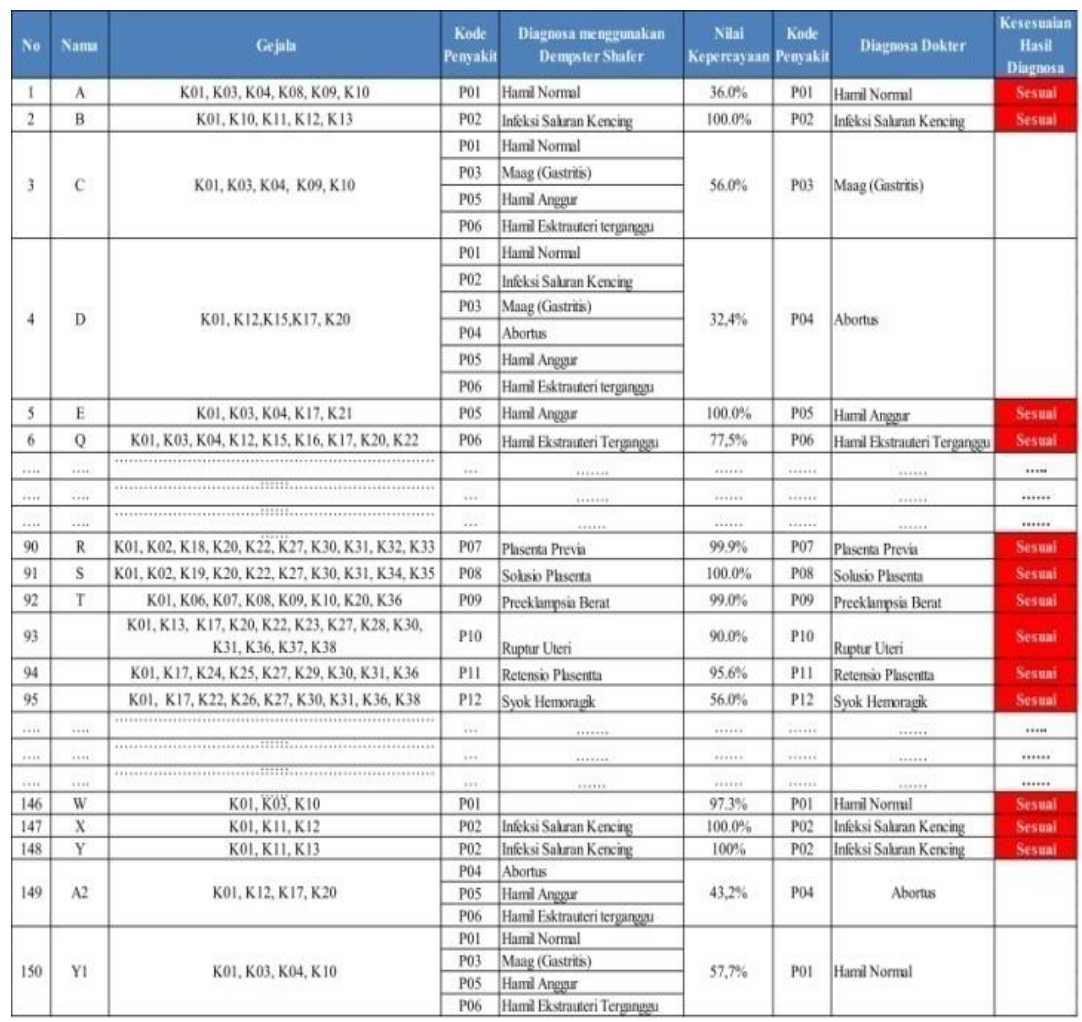

Gambar 7. Hasil pengujian

\subsubsection{Pengujian Validitas Nilai Akurasi Sistem}

Pengujian validitas nilai akurasi sistem dilakukan dengan cara mengambil data dari hasil pengujian rekam medik pasien dengan sistem pakar ini, dalam pengujian tersebut kriteria utama terhadap hasil adalah valid yang merupakan derajat ketepatan antara diagnos dokter dengan sistem yang telah dibuat, dengan demikian data yang valid adalah data yang tidak berbeda antara data dari hasil diagnosa dokter sebanyak 114 data. Dari data tersebut dibandingkan dengan sistem pakar yang telah dibuat dan hasilnya ada beberapa data yang berbeda. Adapun perhitungan perbandingan antara pengujian standar dengan pengujian sistem sebagai berikut : 
Nilai akurasi sesuai :

$$
\begin{aligned}
& =\frac{\text { Jumlah data }- \text { jumlah data tidak sesuai }}{\text { Jumlah data }} \times 100 \% \\
& =\frac{150-36}{150} \times 100 \% \\
& =76 \%
\end{aligned}
$$

Nilai akurasi tidak sesuai :

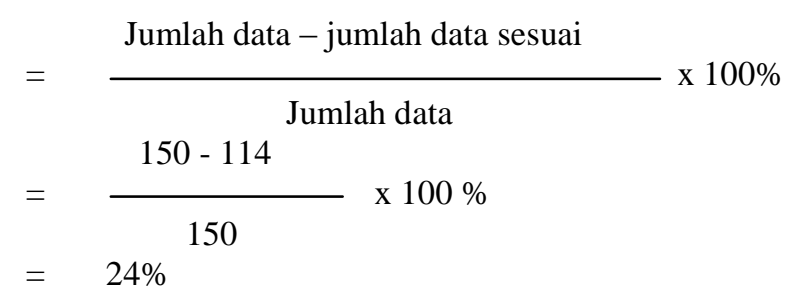

Berdasarkan uji validitas terhadap nilai prediksi hasil diagnposa didapatkan nilai keakurasian sebesar $76 \%$ sedangkan nilai ketidak akurasian predisksi sebesar $24 \%$.Suatu proses pembentukan pohon keputusan dikatakan berhasil jika pohon keputusan yang dihasilkan bisa mengklasifikasikan sampelsampel data secara akurat dengan tingkat kebenaran $100 \%$, namun permasalahannya pada sampel-sampel data yang didapatkan tidak jarang terdapat kesalahan (noise) seperti halnya pada penelitian ini, kesalahan user yang memasukkan data tidak sesuai dengan basis aturan yang sudah ditetapkan, sehingga terdapat kegagalan sebesar $24 \%$ dalam diagnosa penyakit kehamilan. Hal yang harus dilakukan dalam menangani terjadinya kegagalan pada diagnosa ini adalah dengan pemilihan gejala yang sesuai dengan basis aturan dan pohon keputusan yang ada berdasarkan saran pakar.

\section{KESIMPULAN}

Hasil penelitian dapat disimpulkan bahwa, sistem pakar diagnosa penyakit kehamilan dapat digunakan untuk membantu mendiagnosa penyakit kehamilan, Sistem dapat menampilkan hasil diagnosa berupa nama penyakit. Hasil analisis menggunakan metode Dempster-Shafer dan decision tree dari studi kasus yang dilakukan pada Rumah Sakit Dr. Soeharso Pontianak menunjukkan bahwa parameter tingkat kecocokan diagnosa secara keseluruhan sesuai bila data yag dimasukkan sesuai dengan rule yang sudah di tetapkan. Pemanfaatan metode Dempster-Shafer dapat memperkuat diagnosa yang dihasilkan karena sistem tidak hanya bertumpu pada rule, tetapi mempunyai nilai sehingga tingkat kepercayaan lebih akurat didukung dengan decision tree sebagai pendukung dalam mengambil keputusan penyakit

\section{DAFTAR PUSTAKA}

[1] Bari, S., George, A., Gulardi H.W., Djoko, W., 2000, Buku Acuan Nasional Pelayanan Kesehatan Maternal dan Neonatal, Jakarta, JNPKKR-POGI

[2] Lu, Y.H., 2006, Automatic Building Detection Using the Dempster-Shafer Algorithm, Photogrammetric engineering and remote sensing-Australian Research Council

[3] O’Neill, Adrian., 2000, Demspter-Shafer Teory, Website :http://www.aonaware.com/binaries/dempster.pdf, diakses tanggal : 26 Februari 2013.

[4] Maseleno, A., dan Hasan, M., 2012, Avian Influenza (H5N1) Warning System using DempsterShafer Theory and Web Mapping. International Journal of Information and Communication Technology, Vol. 4, No. 2, 2012. ISSN. 1466-6422, pp. 227 - 141.

[5] Sitamahalakshmi, T., Vinaybabu, A., dan Jagadeesh, M., 2010, Character Recognition using Demspter-shafer Theory Combining Different Distance Measurement methods, International Journal of Engineering Science and Technology, (2) , 1177-1184

[6] Suyanto, 2009. Decision tree learning. Bandung,Informatika

[7] Turban, E., 1995, Decision Support and Expert System Management Support System. Newyork , Prentice-Hall.

[8] Zhang, J., 2006, A Dempster-Shafer belief theory based algoritthm for classification of Imperfect data, IADIS European Conference Data Mining, USA 